\title{
Jesuit Cardinals: An Introduction
}

\author{
Robert A. Maryks \\ Independent Scholar, The Berkshires, MA, USA \\ robert.maryks@gmail.com
}

\begin{abstract}
The strong resistance of Ignatius of Loyola $\left(c .1491-155^{6}\right)$, first superior general of the Society of Jesus $\left(1541^{-56}\right)$, to the promotion of his confrères to ecclesiastical offices of (arch)bishops and cardinals because such posts were contrary to the spirit of religious life, requires a brief explanation. Ignatius's opposition was codified in the Jesuit Constitutions with a requirement that each professed Jesuit promise not to accept such dignities. Nonetheless, Loyola and his successors were occasionally pressured to acquiesce to possible papal appointments of different Jesuits to such offices. This issue of the Journal of Jesuit Studies focuses on six of approximately forty-nine cardinals (the definition of Jesuit cardinal can be sometimes tricky for the early modern period). These six represent different historical periods from the late sixteenth until the early twenty-first centuries and different geographical areas, both of origin and of operation (they did not always coincide): Péter Pázmány (1570-1637), Johann Nidhard (1607-81), Giovanni Battista Tolomei (1653-1726), Johann Baptist Franzelin (1816-86), Pietro Boetto (1871-1946), and Adam Kozłowiecki (1911-2007).
\end{abstract}

\section{Keywords}

Jesuit cardinal - Péter Pázmány - Johann Nidhard - Giovanni Battista Tolomei Johann Baptist Franzelin - Pietro Boetto - Adam Kozłowiecki

In the Society's Constitutions, its co-founder Ignatius of Loyola hoped eradicate ambition (ambitus), "origin of all evil in any religious order." ${ }^{11}$ He prescribed,

1 This part of the introduction is based on Jerónimo Aixalá, "Dignidades eclesiásticas," in Diccionario histórico-biográfico de la Compañía de Jesús, ed. Charles E. O’Neill, S.J. and Joaquín M. a Domínguez, S.J. (Rome: I HSI, 2001), 1123-25. See also Ángel Santos Hernández, Jesuitas y 
therefore, that the door be closed to any pursuit of ecclesiastical preferment. Professed Jesuit vows neither to seek nor to accept any ecclesiastical dignity outside the Society of Jesus unless he is compelled to do so under pain of sin (Const., 817). ${ }^{2}$

Cardinal Marcello Cervini (r.1555 [April-May]), one of the presidents of the Council of Trent (who a year later would be elected pope Marcellus II) and Martín de Olabe $(c .1507-56)$, a graduate of the Sorbonne and member of the council, who had entered the Society in 1552, discussed Loyola's unique prohibition in 1554. Cervini argued that the Society would serve the church better by providing it with good bishops. Olabe's explanation of the Society's opposition did not convince the cardinal. Olabe told him candidly that Ignatius's authority seemed sufficient to believe that it was the best way forward. Cervini eventually acquiesced.

Shortly after Juan de Arteaga (d.1540), a former companion of Íñigo in Barcelona and Alcalá, was appointed bishop of Chiapas in Mexico in 1540, offered his bishopric to Ignatius for a member of the new Society of Jesus. Ignatius, who had not yet been elected a superior general, declined the offer. In 1545, Bishop Urban Weber of Laibach (Ljubljana) requested that Diego Laínez (151262 ) be named his coadjutor with right to succession. According to Jesuit historian Giuseppe Boero (1814-84), Laínez was later offered the seats of Florence and of Pisa: he rejected both. Alfonso Salmerón (1515-85) attests that Laínez was also offered the seat of Mallorca. In 1555, Pope Paul IV (r.1555-59) decided to elevate Laínez to the cardinalate. Salmerón warned Ignatius of the danger, as did Cardinal Otto von Truchsess of Augsburg (1514-73). In response, Pedro de Ribadeneyra (1527-1611) repeated what Ignatius had confided to him: "If our Lord does not lay down his hand, we will have Master Laínez a cardinal, but I certify to you, if it were, that it be with so much noise that the world would understand how the Society accepts these things" (MHSI, Fontes narrativi, 2:372).

Emperor Charles V (r.1519-56) and Emperor Ferdinand I (r.1556-64) pressured Jesuits to accept bishoprics. Ferdinand as king of Romans, through the

obispos: Los jesuitas obispos misioneros y los obispos jesuitas de la extinción, 2 vols. (Madrid: Universidad Pontificia Comillas, 1998-2001), 1:21-22.

2 The Complimentary Norms to the Jesuit Constitutions clarify this point as follows: "In regard to accepting the episcopal office, the first response on the part of the one whose appointment is being proposed should always be to make a representation of our vow. This can more easily be done, since the Holy See does not impose an episcopal appointment without the consent of the candidate. But if in a particular case the Holy See insists or some member remains anxious because he has not positively responded immediately to the will of the Holy Father expressly manifested to him, [44] he should refer the matter either directly or through his provincial to the superior general, so that together they may examine the more appropriate way of responding to what is proposed, according to the spirit of our Institute and for the greater glory of God" [139, §3]. 
bishop of Laibach, campaigned for the appointment of Claude Le Jay $\left(1505^{-52}\right)$ to the strategic seat of Trieste (today in north-east Italy). The nomination seemed inevitable until Ignatius managed to dissuade Pope Paul III (r.1534-49) from confirming it.

Other co-founders, first companions were also sought for higher office, specifically Nicolás Bobadilla (1511-90) and Paschase Broët (c.1500-62). In 1551, Charles $\mathrm{V}$ advocated that his friend and confidant Francisco de Borja (1510-72), newly ordained priest and professed of the Society of Jesus, be raised to the purple. Upon learning that Pope Julius III (r.1550 [February-March]) had already agreed to Charles's recommendation, Ignatius apparently mobilized all the spiritual resources at hand. Borja himself left Rome and hid in an obscure corner of the Basque country, where he remained until the pope abandoned the project. Around this time, Ignatius defended the Society against a similar attempt by Pope Julius III. In Vienna, the papal nuncio and the imperial ambassador pressed the pope to appoint Peter Canisius (1521-97) to fill the episcopal vacancy. Finally, a compromise was obtained by a brief by which Canisius was appointed administrator of the Viennese church for a year but without episcopal title or benefits.

However, there were a few exceptions. Loyola allowed the appointment of João Nunes Barreto (c.1519-71) as patriarch of Ethiopia, and André de Oviedo (1518-77) and Melchior Miguel Carneiro Leitão (1519-83) as his coadjutor bishops perhaps because of the pressure of King John III of Portugal (r.1521-57), to whom the young Society was very much indebted (the first Jesuit province was established in Portugal), or because, as John W. O'Malley has suggested, Ignatius "believed that in these instances there was no danger of the episcopacy's being sought because of any honor or benefice attached-indeed, the future promised only extreme hardship." ${ }^{3}$

Resistance continued under Laínez, Borja, and Everard Mercurian (in office 1573-80) but changed during the generalate of Claudio Acquaviva (in office 1581-1615), when Pope Clement VIII (r.1592-1605) created the first Jesuit cardinals - Francisco de Toledo (1532-93) in 1593 and Robert Bellarmine (15421621) six years later in 1599. During the same period, though, with the active assistance of Robert Persons (1546-1610), Acquaviva prevented the promotion of the Englishman as successor to Cardinal William Allen (1532-94). ${ }^{4}$

Forty-nine Jesuits comprise a list of cardinals from the 1590 s to 2020 . Yet, it is unclear whether four can be actually dubbed Jesuit because they were not

3 John W. O'Malley, The First Jesuits (Cambridge, MA: Harvard University Press, 1993), 328.

4 Thomas M. McCoog, S.J., The Society of Jesus in Ireland, Scotland, and England, 1589-1597: Building the Faith of Saint Peter upon the King of Spain's Monarchy (Farnham/Rome: Ashgate/ Institutum Historicum Societatis Iesu, 2012), 247-49. 
members of the Society when they were created cardinals. ${ }^{5}$ Jan Kazimierz Waza (1609-72), who was a Jesuit novice for about a year, became a cardinal and eventually a king; his brother Jan Olbracht Waza (1612-34) had been a Jesuit scholastic for a few years and created cardinal after his departure from the Society. Cardinal Carlo Odescalchi $(1786-1841)$ gave up the purple before he entered the Society of Jesus. Finally, Hans Urs von Balthasar (1905-88), a renown Swiss theologian, was announced to be created cardinal when he was a Jesuit no more for thirty-eight years, and he died two days before the ceremony.

All Jesuit cardinals remained members of the Sacred College until their death $s^{6}$ with the significant exception of Cardinal Louis Billot (1846-1931), who abdicated (or was demoted?) a few years before he died (1927). Five cardinals entered the Society of Jesus and died as Jesuits. Among them Giuseppe Pecci (1807-90), Pope Leo XIII's (r.1878-1903) elder brother, and Niccolò Pecci (171567 ) who was a cardinal for less than a year and made his religious profession close to his death.

Few Jesuit cardinals had been residential bishops. Among them are Bellarmine in Capua, Pázmány in Esztergom, Alvaro Cienfuegos (1657-1739), first in Catania and later in Monreale; Camillo Mazzella (1833-1900) in Palestrina; Boetto in Genoa; Pablo Muñoz Vega (1903-94) in Quito; Lawrence Picachy (1916-92) in Calcutta; Victor Razafimahatratra (1921-93) in Antananarivo; Carlo Maria Martini (1927-2012) in Milan; Ján Chryzostom Korec (1924-2015) in Nitra; and Augusto Vargas Alzamora (1922-200o) in Lima. Johann Eberhard Nidhart (Nithard) and Augustin Bea (1881-1968) were ordained bishops but oversaw no diocese. Henri de Lubac (1896-1991), Paolo Dezza (1901-99), Aloys Grillmeier (1910-98), Avery Dulles (1918-2008), Roberto Tucci (1921-2015), Tomáš Špidlík (1919-2010), Karl Josef Becker (1928-2015), and Urbano Navarrete Cortes $(1920-2010)$ were exempted from the existing law that requires episcopal ordination for all priests promoted as cardinals (Canon Law 351, §1). So far only one Jesuit cardinal was canonized: Bellarmine.

Few Jesuits have been named cardinals because of their special promise not to seek ecclesiastical promotion. Thus, the small but select group includes very

5 It should be noted that once a Jesuit (or any religious) is created cardinal, he is dispensed from his vows of poverty and obedience and remains a member of the Society only nominally and not canonically (Canon Law, 705-6 in reference to bishops but applicable to cardinals dispensed from being ordained bishops). The professed make, however, a promise that should he be ordained bishop (or created cardinal), he "will never refuse to listen to the counsel which the superior general of the Society himself, or someone else of the Society whom he substitutes for himself, will deign to give (Const. 134).

6 The following statistics exclude the current seven Jesuit cardinals (as of May 2020). 
prominent members of the Society. They were accomplished diplomats, confessors to popes and royals, insightful theologians, writers, poets, intellectuals, members of royal and aristocratic families, talented administrators and teachers, and harbingers of change. Some of them, like Bellarmine, Bea, Jean Daniélou (1905-74), Martini, or Jorge Bergoglio (b.1936) who became Pope Francis in 2013, are better known; others have been rather neglected by scholarship. Despite the prominent role most of them played in the history of the Catholic Church and were sometimes even papabili, only one Jesuit cardinal was elected pope.

This issue of the Journal of Jesuit Studies focuses on six Jesuit cardinals representing different historical periods from the late sixteenth until the early twenty-first centuries and different geographical areas, both of origin and of operation (they did not always coincide): Péter Pázmány (1570-1637), Johann Nidhard (1607-81), Giovanni Battista Tolomei (1653-1726), Johann Baptist Franzelin (1816-86), Pietro Boetto (1871-1946), and Adam Kozłowiecki (19112007). The following essays detail their intriguing lives and interesting careers and explore their historiography. We hope that this special issue of the Journal of Jesuits Studies will generate more scholarship on these and other Jesuit cardinals, filling many lamentable lacunae in Jesuit scholarship. 